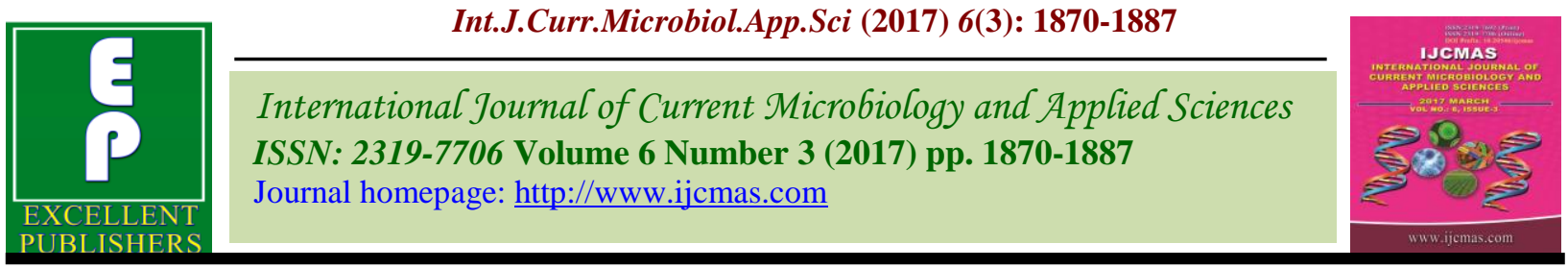

Review Article

https://doi.org/10.20546/ijcmas.2017.603.213

\title{
Bael (Aegle marmelos) Extraordinary Species of India: A Review
}

\author{
Neeraj, Vinita Bisht and Vishal Johar* \\ ${ }^{1}$ Department of Agriculture, Mewar University, Gangrar, Chittorgarh, Rajasthan-312901, India \\ ${ }^{2}$ Department of Forestry, CCS Haryana Agricultural University, Hisar-125004, India \\ *Corresponding author
}

\begin{tabular}{|c|c|}
\hline & A B S T R A C T \\
\hline $\begin{array}{l}\text { Ke y w o r d s } \\
\text { Beal, Rutaceae, Post } \\
\text { harvest and India. }\end{array}$ & \multirow{3}{*}{$\begin{array}{l}\text { Bael, Aegle marmelos (Linn.) Correa ex Roxb., belonging to family rutaceae is a medium } \\
\text { sized tree of Indian origin found upto an altitude of } 1200 \text { meter. Various parts of this } \\
\text { versatile tree species such as leaves, roots, seed, bark and fruit etc contain a large number } \\
\text { of coumarins, alkaloids, sterols and essential oils hence, possess anti-microfilarial, } \\
\text { antifungal, analgesic, anti-inflammatory, antipyretic, hypoglycaemic, antidyslipidemic, } \\
\text { immunomodulatory, antiproliferative, wound healing, anti-fertility, and insecticidal } \\
\text { abilities. The fruits are also used to prepare a large number of by products such as candy, } \\
\text { panjiri, toffee, jam etc with help of various post harvest technologies which also helps to } \\
\text { reduce the post harvest losses and hence increases the shelf life which further helps in } \\
\text { value addition and in generation a good income for a needy farmer. }\end{array}$} \\
\hline Article Info & \\
\hline $\begin{array}{l}\text { Accepted: } \\
\text { 24 February } 2017 \\
\text { Available Online: } \\
10 \text { March } 2017\end{array}$ & \\
\hline
\end{tabular}

\section{Introduction}

Bael (Aegle marmelos Corr.) is an indigenous fruit of India belongs to family Rutaceae and it is commonly known as Bengal quince (John and Stevenson, 1979), Bilva, Indian quince, Golden apple, Holy fruit, Bel, Belwa, Sriphal, Stone apple and Maredo in India. Aegle marmelos (L.) tree is held sacred by hindus and offered in prayers of deities Lord Shiva and Parvati and thus the tree is also known by the name Shivaduma (The Tree of Shiva). It has tolerance to arid conditions (Chundawat, 1990) as well as high rainfall. Exploration undertaken in eastern Uttar Pradesh and adjoining urea of Bihar indicated wide range of variability in thorniness on stem, fruit shape, scull thickness and pulp characteristics. Promising lines in respect to high yield and quality fruits were identified (Rai et al., 1991).
The Bael tree has its origin from Eastern ghats and central India. It's indigenous to Indian subcontinent and mainly found in tropical and sub-tropical regions. The tree is also found as a wild tree, in lower ranges of Himalyas up to an elevation of 500 meters. Bael is also found growing along foothills of Himalayas, Uttranchal, Jharkhand, Madhya Pradesh and the Deccan Plateau and along the east coast (Sharma et al., 2007). Bael fruit is a sub-tropical, deciduous tree and fruit is globuse with grey or yellowish hard woody shell. Inside this, there is soft yellow or orange colored mucilaginous pulp with numerous seeds. It has numerous seeds, which are densely covered with fibrous hairs and are embedded in a thick, gluey, aromatic pulp (Kaushik et al., 2002). Bael fruit is truly popular for its ability to combat constipation. 
Its medicinal properties have been described in the ancient medical treatise in Sanskrit in CharakaSamhita (Aiyer, 1956). All the plant parts like leaves, roots, barks, seeds and fruits of Bael are important ingredients of several traditional formulations against various diseases and many bioactive compounds have also been isolated of it (Badam et al., 2002, Gupta and Tondon 2004). Bael (Aegle marmelos) is an important medicinal plant of India. Biochemical compounds of bael leaves, fruits and seeds have been used in several diseases like diabetes, cardiovascular and anti-inflammatory (Maity et al 2009). The most important ingredients present in plants are alkaloids, terpenoids, steriods, phenols glycosides and tannins (Venkatesan et al 2009).

\section{Origin}

Bael is native to India (Zeven and De Wet 1982) and found throughout Southeast Asia. In India this fruit is grown in Indo-Gangetic plains and Sub-Himalayan tracts up to a height of $500 \mathrm{~m}$, in North-East India and dry and deciduous forest of central and southern India.

\section{Distribution}

Aegle marmelos is a subtropical plant and grows up to an altitude of 1,200 m altitude from sea level. It grows well in the dry forests on hilly and plain areas. Aegle marmelos is a widely distributed plant and found in India, Ceylon, China, Nepal, Sri Lanka, Myanmar, Pakistan, Bangladesh, Nepal, Vietnam, Laos, Cambodia, Thailand, Indonesia, Malaysia, Tibet, Sri Lanka, Java, Philippines and Fiji.

In India it found in Sub-Himalayan tracts from Jhelum eastwards to West Bengal, in central and south India. It found almost in all the states of India (Dhankar et al., 2011).

\section{Botanic description}

Aegle marmelos is a slow-growing, medium sized tree, up to $12-15 \mathrm{~m}$ tall with short trunk, thick, soft, flaking bark, and spreading, sometimes spiny branches, the lower ones drooping. Young suckers bear many stiff, straight spines. A clear, gummy sap, resembling gum Arabic, exudes from wounded branches and hangs down in long strands, becoming gradually solid. It is sweet at first taste and then irritating to the throat. Bael has enormous traditional uses against various diseases and many bioactive compounds have been isolated from this plant also (Maity et al., 2009).

The deciduous, alternate leaves, borne singly or in 2's or 3's, are composed of 3 to 5 oval, pointed, shallowly toothed leaflets, $4-10 \mathrm{~cm}$ long, 2-5 cm wide, the terminal one with a long petiole. New foliage is glossy and pinkish-maroon. Mature leaves emit a disagreeable odor when bruised. Fragrant flowers, in clusters of 4 to 7 along the young branchlets, have 4 recurved, fleshy petals, green outside, yellowish inside, and 50 or more greenish-yellow stamens (Orwa et al., 2009).

\section{The plant}

Aegle marmelos is a slow-growing, medium sized tree, 25 to 30 feet tall. The stem is short, thick, soft, flaking bark, and spreading, sometimes spiny branches, the lower ones drooping. Young suckers bear many stiff, straight spines. There are sharp, axial one inch long spikes on this tree. The leaflets are oval or lancet shaped, $4-10 \mathrm{~cm}$ long, $2-5 \mathrm{~cm}$ wide. Leaves composed of 3 to 5 leaflets in it. The lateral leaflets are without petiole and the terminal one has a long one. The petiole is 1 to 2.5 inch long. Mature leaves emit a peculiar fragrance when bruised. Flowers occurs in clusters of 4 to 7 along the young 
branchlets, have 4 recurved, fleshy petals. The flowers are greenish white in color with a peculiar fragrant. Flowering occurs during the month of May and June. Fruit is spherical or oval in shape with a diameter of 2 to 4 inch. Shell is thin, hard and woody in nature. It is greenish when unripe and upon ripening it turns into yellowish colour. The pulp of the fruit has 8 to 15 segments. The pulp is yellow, soft, pasty, sweet, resinous and fragrant. Fruition occurs in the month of May and June. The seeds are embedded in the pulp. The seeds are small (nearly $1 \mathrm{~cm}$ in length), hard, flattened-oblong, bearing woolly hairs and each enclosed in a sac of adhesive (Lambole et al., 2010).

\section{Cultural practices of bael}

\section{Climate and soil}

Though bael is a fruit crop of subtropical origin, it has got a wider adaptability and can perform equally well in tropical, arid and semi-arid regions. Aegle marmelos is said to do best on rich, well-drained soil, but it has grown well and fruited on the oolitic limestone of southern Florida. It also grows well in swampy, alkaline or stony soils having $\mathrm{pH}$ range from 5 to 8 . This tree requires pronounced dry season to give fruit. In India it has the reputation of thriving where other fruit trees cannot survive (Hiremarh et al., 1993).

\section{Planting}

Rainy season is the best time for planting. However, planting can also be done in spring season if irrigation facilities are available. Dig the planting pits of $1 \mathrm{~m} \times 1 \mathrm{~m} \times 1 \mathrm{~m}$ size at least one month prior to onset of monsoon. Keep the planting pits open for 20-25 days thereafter; fill each pit with a mixture of top soil and $10-15 \mathrm{~kg}$ of FYM. This may be followed by irrigation to settle down the soil in pits. If depression takes place due to irrigation, add pit filling mixture to the pit. Plant the bael sapling at the center of pit and provide support to the plant. Make a basin around it and irrigate gently. Do mulching with dry leaves to conserve moisture.

\section{Irrigation}

Young plants need to be watered regularly in summer and one month interval in winter for their rapid vegetative growth and establishment. In bearing trees irrigation is not required in dry summer, as it sheds leaves and resists hot dry summers. Irrigation can be applied at the time of new leaf emergence.

\section{Harvesting and yield}

Budded and grafted plants start fruiting after 4-5 years of planting whereas, seedlings after 8-10 years of planting. Bael Fruit takes around 8-10 months to mature and 10-12 months for ripening after fruit set. Bael is climacteric fruit that can be ripened, off the tree, if harvested at proper maturity stage. Maturity can be judged by the change in skull colour from dark green to yellowish green. Mature fruit should be harvested individually with $5 \mathrm{~cm}$ fruit stalk. A full grown (10-12 years old) budded or grafted bael tree produces on an average 150-200 fruits under good management practices. The fruits can be stored at room temperature for two weeks. At $10^{\circ} \mathrm{C}$, it can be kept up to three months. The average yield is 300-400 fruits per tree (Parmer 1982). The quality of fruits is greatly associated with the weight and size of the 
seed-sacs. The larger and heavier the seed sacs, the greater is the amount of mucilage and poorer the quality.

\section{Training and pruning}

Bael trees may be trained in modified central leader. Pruning is done twice in a year, once in May and other in August. Pruning is limited to the removal of dead and diseased twigs/branches in May while in August healthy leaves are pruned for sale.

\section{Propagation of bael}

\section{Vegetative propagation}

The fruit plants propagated by vegetatively are true to type, and as a result, it is possible get uniformity in growth, yield and quality of fruits. Vegetative propagated fruit trees come in to bearing earlier as compared to seedling, while bael is commonly propagated from seeds and root suckers. Organized orcharding of bael are not available due to lack of recognized cultivars and well accepted vegetative propagation techniques. Singh (1954) and Moti et al. (1976) obtained preliminary success through patch budding during May and June in north India. However, detailed information with respect to duration and techniques of its propagation are lacking. Hence, the present investigation was undertaken to standardize the ideal duration and technique of budding for maximizing the success.

Bael (Aegle marmelos L.), considered to be a packhouse of nutrients and medicine, is one of the most neglected and underutilized fruit crops. In spite of possessing a good amount of nutritional and medicinal properties for mankind, little attention has been paid to its cultivation, research and development. Due to its Indian origin, a wide genetic base is available throughout the country, and this needs to be conserved and explored. As Bael is a cross-pollinated crop propagated by seed, a wide variability in exists its population. Vegetative propagation ensures multiplication of selected, elite clones for commercial cultivation and conservation in situ / ex situ. A number of workers have suggested that budding was the best method, although the time of propagation varied from place to place (Kumar et al., 1995; Tripathi and Kumar, 2004). At present, softwood method of wedge-grafting is very popular in many fruit crops like jamun (Madalageri et al., 1991), sapota (Pampanna and Sulikeri, 2000) and custard apple (Ghosh et al., 2004).

\section{Micropropagation}

Micropropagation by enhanced axillary shoot proliferation from mature single node (Raghu et al., 2007) had reported an efficient and rapid in vitro clonal propagation of the endangered medicinal tree Aegle marmelos (L.) Corr. (Rutaceae) by enhanced auxiliary shoot proliferation from mature single node was designed. The explants showed marked seasonal variation in their response under in vitro conditions. Explants collected in October (72.8\%) and November (78.6\%) showed maximum response. Multiple shoots were formed on Murashige and Skoog (MS) medium supplemented with $0.5 \mathrm{mg} \mathrm{L-1} 6$ Benzyladenine (BA). An average of 6.2 shoots/explants could be obtained after 45 days of culture. The number of shoots was increased at the third subculture with an average of 16.3 shoots per explants. The effect of subsequent subcultures (upto 20 cycles) on shoot formation was also studied. Sub culturing was carried out every 45 days on fresh shoot multiplication medium. Continuous culture in the same medium resulted in distorted and vitrified shoots. Transfer of cultures to half strength MS medium devoid of ammonium ions and cytokinin (BA) for a single cycle before going 
to the shoot multiplication medium with different auxins (Indole 3- butyric acid-IBA, Indole 3 -acetic acid-IAA and $\alpha$-naphthalene acetic acid-NAA) at varying concentration and combinations. But in vitro raised shoots could be rooted ex vitro by pulse treatment with naphthoxy acetic acid (NOA) and IBA and then in chlorogenic acid followed by planting in moist sand. This treatment resulted in $83.9 \%$ survival of plantlets. The method standardized could be used for large scale planting material production and conservation of this important endangered medicinal tree (Gupta et al., 2008).

\section{Micropropagation of Bael via the nodal explants}

Gupta et al. (2008) had reported a protocol for micro propagation of Bael (Aegle marmelos (L.) Corr.). Bael (family Rutaceae) is an indigenous medicinally important fruit of India. The nodal explants of 30 year old tree were used to initiate cultures. Two cytokinins, viz., 6-benzylaminopurine (BAP) and kinetin $(\mathrm{Kn})$ were used in varied concentration $(0.1-2$ $\mathrm{mg} / \mathrm{l})$ for shoot multiplication. BAP (2 mg/l) was found better than $\mathrm{KN}$, where a 3-fold increase in the number of shoots was recorded in 4 weeks. A synergistic influence of cytokinin and auxin was also observed in the present study. A combination of $0.5 \mathrm{mg} / \mathrm{l}$ BAP and $0.1 \mathrm{mg} / \mathrm{l}$ IAA induced the formation of maximum number $(4.5)$ of shoots $(2.5 \mathrm{~cm})$. For rooting of in vitro shoots, different auxins, namely, NAA, IAA and IBA (0.1-2 $\mathrm{mg} / \mathrm{l})$ were tested. IAA $(0.01 \mathrm{mg} / \mathrm{l})$ was found better than NAA and IBA. It was concluded that elite cultivars of Bael can be micro propagated, without undergoing callus phase, using the BAP $(0.5 \mathrm{mg} / \mathrm{l})$ plus IAA $(0.1 \mathrm{mg} / \mathrm{l})$ for shoot multiplication and IAA $(0.1 \mathrm{mg} / \mathrm{l})$ for rooting, to produce true-to-type in vitro plants. The in vitro raised plantlets were acclimatized with $30 \%$ success.

\section{In-vitro culture}

Ajit kumar and Seeni (1998) had reported Rapid clonal multiplication of Aegle marmelos (L.) Corr. (Rutaceae), a medicinal tree, was achieved by enhanced axillary bud proliferation in young single-node segments of a 25-year-old tree cultured in Murashige and Skoog (MS) nutrient medium. Bud break was dependent on cytokinin supply, but the synergistic combination of $2.5 \mathrm{mg}^{-1} 6-$ benzylaminopurine (BAP) and $1.0 \mathrm{mg} \mathrm{l}^{-1}$ indole-3-acetic acid (IAA) induced the formation of 12.1 shoots of up to $5.2 \mathrm{~cm}$ length in $48 \%$ of the explants after 7 weeks of culture. Explants of in-vitro-grown shoots node, whole leaf, shoot tip and internodes were subcultured in the presence of $0.05-2.5$ mg 1-1 BAP to produce 11.3, 18.4, 5.3 and 3.2 shoots and shoot buds at a 100\%, 70\%, $95 \%$ and $40 \%$ rate respectively, in 7 weeks. Different shoot nodes and leaves were equally regenerative and adventitious organogenesis in the latter was confined to cut petiolar ends.

Nodal explants responded most favorably at low BAP $\left(0.05-0.1 \mathrm{mg} \mathrm{l}^{-1}\right)$ and produced uniform $(3.8-5.3 \mathrm{~cm})$ shoots facilitating their simultaneous harvest for rooting. Repeated sub culturing through five cycles of nodes and leaves of shoot cultures enabled continuous production of healthy callus-free shoots without any sign of decline. Shoot cuttings $(3.0-5.2 \mathrm{~cm})$ were best rooted in half-strength MS medium with $0.5 \mathrm{mg} \mathrm{l}^{-1}$ IAA $(70 \%)$ or $10.0 \mathrm{mg} \mathrm{l}^{-1}$ indole-3-butyric acid (90\%). Eighty-eight percent of the rooted plants were established in polybags after hardening. Micropropagation techniques have been gainfully employed in mass multiplication of various fruit species (Mishra et al., 2005). Clonal micropropagation of Aegle marmelos from mature nodal explant has been developed by Varghese et al. (1993) and Ajithkumar and Seeni (1998). 
In vitro plant regeneration via organogenic callus culture

Prematilake et al. (2006) had reported a tissue to plant regeneration system for Aegle marmelos (L.) Corr. using cotyledon tissues. This system was applicable to immature leaf and root tissues at lower efficiency. This procedure involved organogenic calli formation on a MS-based medium fortified with Zeatin or 6-furfurylamine (KN) $(2.0 \mathrm{mg} / \mathrm{l})$ and NAA $(0.5 \mathrm{mg} / \mathrm{l})$ under dark conditions. These calli later developed shoots when transferred to hormone-free medium and under illumination. Separated shoots continued to grow in liquid medium, free of hormones and produced roots at $30 \%$ efficiency in the presence of NAA $(1.0 \mathrm{mg} / \mathrm{l})$. Rooted plants survived well under acclimatization. This protocol is suitable to produce number of plants from cotyledon, hypocotyls and immature leaves of Aegle marmelos.

\section{Cross pollination}

The significance of pollination increasing fruit set varies greatly in different cultivars depends upon the amount of functional pollen, facilities of pollens, the relation of pollen to setting the seed and its ability of some varieties to produce fruits parthinocarpically either with or without pollination (Randhwa and Chadha 1982). Crossing between Pant 'Shiwani x Pant Sujhata' gave the highest fruit set $(67.36 \%)$, final fruit retention $(27.04 \%)$. Fruit set and fruit retention under selfing were low compared to croos pollination in different bael cultivars (Mahendra Pal and Mishra 2005).

Highest fruit set in open pollination condition is might be due to the fact that Bael is a self pollinated crop. It is also observed that temperature and humidity were high during the fruit set period (June) which might resulted in drying of pistils and lower pollen retention when crosses were made between the varieties. Open pollination resulted in more fruit set than cross pollination was also reported in peach and almond (Dhaliwal, 1977 and Aulakh and Uppal, 1991). The highest value of fruit drop was registered with Pant Sujata under open pollination while the treatment Pant Shivani x Pant Sujata followed by Pant Bael $10 \times$ Pant Shivani found to be effective in reducing fruit drop to a large extent and provided least fruit drop during both the years of experiment. Our studies on cross pollination also confirm that final fruit retention under open pollination was extremely low i.e, Pant Sujata, Pant Shivani and Pant Bael 10. The fruit retention from different crosses were found to be significantly higher over cross pollination irrespective of source of pollen. The crossing between Pant Shivani x Pant Sujata was found to be most effective in increasing fruit retention followed by Pant Bael 10 x Pant Shivani. Similarly, the higher fruit retention and reduced fruit drop under cross pollination were also observed in Bael (Mahendra Pal and Misra 2005) and lime (Kitat et al., 1973).

\section{Effect of plant growth regulators}

Developing fruits need auxin in higher quantity and fruit drop occurs when auxin level goes down, by exogenous application, the deficiency of auxin is met and thus check fruit drop. However, the different concentration of growth substances i.e., GA3, 2, 4-D, Noxa and 2,4,5-T did not reduce the fruit drop in Aegle marmelos (Pramanik and Bose, 1974). Foliar spray of GA3 at $60 \mathrm{ppm}$ recorded the lowest fruit drop (75\%) and highest fruit set (16.6\%) and yield (164 $\mathrm{kg} / \mathrm{plant}$ ) in ber cv. Umran whereas treatments of fungicides like Bavistin and Blitox-50 had very little or no effect on fruit drop (Singh et al., 2001). 
The maximum fruit set was recorded in NAA 30 ppm followed by GA3 100 ppm and NAA 20 ppm. Similar results on the effect of NAA and GA3 on fruit set was reported in Ber (Singh et al., 2001 and plum (Saini and Sharma, 2010). It is clear from the data that effect of plant growth regulators on fruit drop and fruit retention percentage was superior from control during both the years of experiment. Minimum fruit drop and maximum fruit retention were observed in NAA 20 ppm followed by 2, 4-D 20 ppm. Similar results have been reported in Ber (Bal and Randhawa, 2007).

A significant reduction in percentage of fruit peel content was observed by different sprays of plant growth regulators during both the years of experiment. Minimum fruit peel content was observed in NAA 20 ppm and maximum in control. Fruits treated with plant growth regulators have thinner peel due to cell expansion (Rani and Brahmachari, 2001). Fruit pulp content significantly varied by the application of plant growth regulators in both the years of experiment. The mean of two years showed the maximum fruit pulp content in NAA $20 \mathrm{ppm}$ and minimum fruit pulp content in ethrel $50 \mathrm{ppm}$. Similar effect of NAA was reported in Ber (Singh et al., 2001) and Nagpur mandarin (Ansari et al., 2008). The increase in pulp weight might be due to accumulation of more water and food substances in the aril along with increase in size of cells and intercellular spaces due to sprays of plant growth regulators. GA3 has been found very effective in inducing parthenocarpy or reducing the size and weight of seeds (Srivastava and Singh, 1969).

\section{Effect of mineral nutrients on control of fruit drop}

Boron promoted absorption and metabolism of sugars and helped synthesis of pectic substances for the cell wall of actively elongated pollen tubes indicating that boric acid played an important role in wall structure of the tube membrane (Munzner, 1960). Boron is also known to improve stigma receptivity thus resulting in better pollination and fruit set. Among the different sprays of mineral nutrients, borax $1.0 \%$ was found effective and resulted in minimum fruit drop and maximum fruit retention. While, the maximum fruit drop and minimum fruit retention were observed in control. Similar results have been reported in Bael (Saini et al., 2004). Reduction in fruit drop by sprays of mineral nutrients may be due to a better availability of nutrient and growth regulators particularly the auxins which play an important role in fruit growth and development. Improvement in fruit retention percentage due to spray of micronutrients might be attributed to reduction in fruit drop. Boron spraying increased cell division and cell enlargement as well as the biosynthesis of carbohydrates and proteins which causes increase in pulp weight. Significant differences were observed for fruit fibre, mucilage and non-edible portion of fruit by application of mineral nutrient during both the years of experiment. Spray of borax $1.0 \%$ resulted in minimum fruit fibre, mucilage and non edible portion of fruit.

\section{Fruit cultivars of Aegle marmelos}

There are no standardized names for Aegle marmelos cultivar. They are given names on the basis of locality where these are found. Fruits of different cultivars were of different shapes and sizes, such as spherical, oblong, cylindrical, pear-shaped and flat. Fruit weight also varied in different cultivars. The percentages of peel, seeds and contents of other fibres also varied. There are reports available on the cultivars of Bael mainly from Uttar Pradesh and Bihar states of India (Teaotia et al., 1963 and Jauhari 1971). Around twelve cultivars, viz., 'Basti No.1', 
'Gonda No.1', '2' and '3', 'Kagzi Etawah', 'Sewan Large', 'Deoria Large', 'Chakaiya', 'Lamba', and 'Baghel' has been reported. 'Kagzi Etawah', 'Sewan Large', 'Deoria Large' and 'Mirzapuri', have been found to be superior and better than the other varieties in case of taste and qualities. Four cultivars viz., 'Narendra Bael-4' 'Narendra Bael-5', 'Narendra Bael-7', 'Narendra Bael-9' 'Narendra Bael-16' and 'Narendra Bael-17' have been identified and studied by Srivastava and Singh (2004). They experimented to evaluate these commercially important cultivars and found that the heaviest fruit weight was recorded in 'Narendra Bael-7', whereas minimum fruit weight, fruit length and fruit breadth recorded was of 'Narendra BaeI-4'. Fibre content and seed/fruit were recorded minimum in 'Narendra Bael-9' and maximum in 'Narendra Bael-5'. Maximum total soluble solid, ascorbic acid and total sugar content recorded in 'Narendra Bael-5'. Though, minimum total soluble solids, ascorbic acid and total sugars were recorded in 'Narendra Bael-7' (Hayes, 1957). A number of cultivars have been selected recently which are the best among the others with regards to yield and fruit quality. Narendra Bael-5 and 9 are popular among the farmers of Uttar Pradesh. These are;

'NB 5'-Fruit size is medium, round in shape having smooth surface at maturity, low mucilage, moderately fibrous and have soft flesh with excellent taste.

'NB 6'-Fruit size is medium, round with smooth surface, and have thin rind, few seeds, soft flesh, low mucilage and mild acidic.

'NB 16'- Elliptical round, pulp yellow, Av. weight $1.3 \mathrm{~kg}$, TSS $31 \%$, medium seed and low fibre content.

'NB 17'- Fruits oblong, big sized, fruit quality excellent, seed content less.
'Pant Shivani'-Mid season cultivar with ovoid oblong shape, size $2 \mathrm{~kg}$, colour lemon yellow on ripening, fiber and mucilage content medium, rind medium thick, pulp light yellow with very good taste and pleasant flavor (Gupta 1999).

'Pant Bael-10'-This variety was found highest yield (Jaiswal 1997).

'Pant Aparna'-late cultivar with small fruit size $(0.6-0.8 \mathrm{~kg})$, globose shape, and seed, mucilage, fibre and acidity are low. Its Flesh is yellow, sweet, tasty and having good flavor.

'Pant Urvashi' - 'Pant Urvashi' were found to be best on yield and yield characteristics (Gupta 1999).

Macronutrient content of leaves among four varieties of Bael viz. Pant Aparna, Pant Shivani, Pant Sujata and Pant Urvashi does not differ significantly except the calcium content of leaves which shows significant difference among four varieties during both the year of experiment. Maximum calcium content of leaves was observed in Pant Aparna and minimum calcium content of leaves was found in Pant Urvashi. The average nitrogen, phosphorus, potassium, calcium and magnesium content of leaves are $0.88-0.98 \%, 0.29-0.35 \%, 1.02-1.19 \%, 1.29-$ $1.82 \%$ and $0.34-0.42 \%$, respectively. The mean levels of the macronutrient in leaves were found optimum in all the varieties in comparison to the critical limit of macronutrient in Bael as calculated on dry weight basis (Srivastava, 2008).

\section{Tree management}

The tree has no exacting cultural requirements, doing well with minimum of fertilizer and irrigation. The spacing in orchards is 6-9 $\mathrm{m}$ between trees. Seedlings begin to bear in 6-7 years vegetative 
propagated trees in 5 years. Full production is reached in 15 years. Normally the fruit is harvested when yellowish-green and kept for 8 days while it loses its green tint. Then the stem readily separates from the fruit. A tree may yield as many as 800 fruits in a season (Lambole et al., 2010).

\section{Chemical constituent}

Extensive investigations have been carried out on different parts of Aegle marmelos and as a consequence, varied classes of compound viz., alkaloids, coumarins, terpenoids, fatty acids have been isolated from its different parts. Aegle marmelos leaves contained $\gamma$ sitosterol, aegelin, lupeol, rutin, marmesinin, $\beta$-sitosterol, flavones, glycoside, oisopentenyl halfordiol, marmeline and phenylethyl cinnamamides. The detailed investigations on isolated compound classes are as under :-

\section{Alkaloids}

The alkaloids comprise the largest single class of secondary plant substances. New alkaloids from the leaves of Aegle marmelos were reported viz., halfordino, ethylcinnamamide and marmeline. Recently, series of phenylethyl cinnamides, which included new compounds named anhydromarmeline, aegelinosides $\mathrm{A}$ and $\mathrm{B}$ were isolated from Aegle marmelos leaves as $\alpha$-glucosidase inhibitors (Yadav et al., 2009).

\section{Terpenoids}

The essential oils of Aegle marmelos (L.) correa leaves were studied very much extensively in India by various workers since 1950. $\alpha$-Phellandrene was found to be the common constituent of the essential oil from leaves, twigs and fruits. $\alpha$-Phellandrene $(56 \%)$ and p-cymene $(17 \%)$ were reported from leaf oil. Limonene $(82.4 \%)$ was reported as the main constituent from Aegle marmelos leaves and it was shown that limonene is characteristics marker for identification of Aegle marmelos oil samples (Yadav et al., 2009).

\section{Carotenoids}

Carotenoids are responsible for imparting pale colour to fruit. Marmelosin, skimmianine and umbelliferone are the therapeutically active principles of bael plant. Minor constituents like ascorbic acid, sitosterol, crude fibres, tannins, $\alpha$-amyrin, carotenoids and crude proteins are also present (Hiremarh, et al., 1996).

\section{Tannins}

There is as much as $9 \%$ tannin in the pulp of wild fruits, less in cultivated type. Tannin is also present in leaves as skimmianine. It is also named as 4, 7, 8-trimethoxyfuroquinoline (Daniel, 2006).

Table.1 Nutritional value of Bael Fruit (\% or per 100 g) (Source: Purohit et al., 2004, Shankar, 1969 and Paricha, 2004)

\begin{tabular}{|c|c|c|c|}
\hline Components & Value (\%) & Components & Value (\%) \\
\hline Water (moisture) & 64.2 & Potassium & 0.6 \\
\hline Protein & 1.8 & Iron & 0.3 \\
\hline Fat & 0.2 & Vitamin A (IU) & 186 \\
\hline Mineral & 1.5 & Vitamin B1 & 0.01 \\
\hline Fiber & 2.2 & Nicotinic acid & 0.9 \\
\hline Carbohydrate & 30.6 & Riboflavin & 1.2 \\
\hline Calcium & 0.09 & Vitamin C & 0.01 \\
\hline Phosphorus & 0.05 & Calorific value & 129 \\
\hline
\end{tabular}




\section{Pharmacological properties}

\section{Anti-microfilarial activity}

Methanolic extract of roots of vitex negundo $\mathrm{L}$. and extracts of leaves of vitex negundo $\mathrm{L}$. Ricinus communis L. and Aegle marmelos corr. were explored for possible antifilarial effect against Brugia malayi microfilariae. It was observed that among the herbal extract, root extract of vitex negundo $\mathrm{L}$ and leaves extract of Aegle marmelos Corr. At $100 \mathrm{ng} / \mathrm{ml}$ concentration showed complete loss of motility of microfilariae after $48 \mathrm{hrs}$ of incubation. Thin layer chromatography of the extracts revealed the presence of alkaloids, saponins and flavonoids in the roots of vitex negundo $\mathrm{L}$ and coumarin in the leaves of Aegle marmelos Corr. (Sahare et al., 2008).

\section{Antifungal activity}

The compound exhibited significant antifungal activity against pathogenic strains of Aspergillus species and Candida albicans in disc diffusion assay (MIC value of 6.25 $\mu \mathrm{g} / \mathrm{disc})$, microbroth dilution and percent spore germination inhibition assays (MIC value of $31.25-62.5 \mu \mathrm{g} / \mathrm{ml}$ ) (Mishra et al., 2010). The antifungal activity of essential oil isolated from the leaves of bael (Aegle marmelos (L.) Correa ex Roxb; Rutaceae) has been evaluate using spore germination assay. The oil exhibited variable efficacy against different fungal isolates and $100 \%$ inhibition of spore germination of all the fungi tested was observed at $500 \mathrm{ppm}$. However, the most resistant fungus, Fusarium udum was inhibited $80 \%$ at $400 \mathrm{ppm}$. Kinetic studies showed concentration as well as time dependant complex inhibition of spore germination by essential oil (Rana et al., 1997). Patil R. H (2009) reported the antifungal activity of ethanolic extract of the Aegle marmelos leaves including antidiarrhoeal, and antimicrobial, activities. Rana B. K. (1997) evaluated anti fungal activity of essential oils isolated from the leaves of Bael using spore germination assay. The oil exhibited variable efficacy against different fungal isolates and $100 \%$ inhibition of spore germination of all the fungi tested was observed at 500ppm. They proposed that essential oil from bael leaves may interfere with the $\mathrm{Ca}^{2+}$-dipicolonic acid metabolism pathway and possibly inhibit the spore formation (Rana et al., 1997). Pitre S and Srivastava S.K., ( 1987), demonstrate the antifungal activity of ethanolic root extract against Aspergillus fumiganus and Trichphyton mentagrophytes.

\section{Analgesic}

The methanol extract of leaves of Aegle marmelos at a dose level of 200 and 300 $\mathrm{mg} / \mathrm{kg}$ showed significant analgesic activity on acetic acid-induced writhing and tail flick test in mice (Shankarananth et al., 2007).

\section{Anti-inflammatory, antipyretic and analgesic}

The serial extracts of the leaves of Aegle marmelos Corr. were investigated for antiinflammatory property. The analgesic and antipyretic properties were also evaluated. The most of the extracts derived from the plant Aegle marmelos caused a significant inhibition of the carrageenan-induced paw oedema and cotton-pellet granuloma in rats. The extracts also produced marked analgesic activity by reduction the early and late phases of paw licking in mice. A significant reduction in hyperpyrexia in rats was also produced by the most of the extracts. This study was established anti-inflammatory, antinociceptive and antipyretic activities of the leaves of Aegle marmelos (Arul et al., 2005). 


\section{Immunomodulatory activity}

The aim of the present study was to investigate the immunomodulatory action of methanolic extract of Aegle marmelos fruit (FEAM) in experimental model of immunity. Methods: Cellular immunity was carried out by neutrophil adhesion test and carbon clearance assay, whereas, humoral immunity was analyzed by mice lethality test and indirect haemagglutination assay. FEAM dose was selected by Stair case method (up and down) and administered at 100 and 500 $\mathrm{mg} / \mathrm{kg}$ orally. The Ocimum sanctum (OSE, $100 \mathrm{mg} / \mathrm{kg}$, p.o) was used as standard. FEAM at 100 and $500 \mathrm{mg} / \mathrm{kg}$ produced significant increases in adhesion of neutrophils and an increase in phagocytic index in carbon clearance assay. Both high and low doses of FEAM significantly prevented the mortality induced by bovine Pasteurella multocida in mice. Treatment of animals with FEAM and OSE significantly increased the circulating antibody in indirect haemagglunation test. Among the different doses, low one was more effective in cellular immunity models than the high. However, all the doses exhibited similar protection in humoral immunity procedures. From the above findings, it is concluded that FEAM possesses potential for augmenting immune activity by cellular and humoral mediated mechanisms more at low dose (100 $\mathrm{mg} / \mathrm{kg}$ ) than high dose $(500 \mathrm{mg} / \mathrm{kg}$ ) (Patel et al., 2010).

\section{Antiproliferative activity}

In the present paper we show that extracts from Aegle marmelos Correa are able to inhibit the in vitro proliferation of human tumor cell lines, including the leukemic
K562, T lymphoid Jurkat, Blymphoid Raji, erythroleukemic HEL, melanoma Colo38, and breast cancer MCF7 and MDAMB- 231 cell lines. Molecules present within the studied Aegle marmelos $\mathrm{C}$. extracts were identified by gas-chromatography/mass spectrometry analysis; three derivatives (butyl p-tolyl sulfide, 6- methyl-4-chromanone and butylated hydroxyanisole) were found to exhibit strong activity in inhibiting in vitro cell growth of human K562 cells. The antiproliferative activity of these compounds was found to be comparable to that of known antitumor agents, including cisplatin, chromomycin, cytosine arabinoside and 5fluorouracil. In addition, the antiproliferative activity of butyl-p-tolyl sulfide, 6-methyl-4chromanone and 5-methoxypsolaren was associated to activation of the differentiation pattern of K562 cells (Lampronti, et al., 2003).

\section{Wound healing activity}

Effect of topical and intraperitoneal administration of methanolic extract of Aegle marmelos ointment and injection was studied respectively on two types of wound models in rats, the excision and the incision wound model. Both the injection and the ointment of the methanolic extract of Aegle marmelos produced a significant response in both of the wound type tested.

In the excision model the extract treated wounds were found to epithelialize faster and the rate of wound contration was higher, as compared to control wounds. The extract facilitated the healing process as evidenced by increase in the tensile strength in the incision model. The results were also comparable to those of a standard drug nitrofurazone (Jaswant et al., 2001). 


\section{Traditional uses}

Bael species act as a climate purifier by absorbing poisonous gas from the atmosphere. The products obtained from Bael are highly nutritive as well as therapeutic. The juice of the fruit gives comfort from constipation and dyspepsia. The fruits are used against viral and intestinal parasites. The fruits are used to prepare squashes and cold drinks. The unripe fruits can be used after roasting. It can be used for the treatment of tuberculosis and gynecological disorders.

Bael leaves are useful in jaundice and in the treatment of wounds. The extract of leaves is beneficial in the treatment of leucorrhoea, conjunctivitis and deafness. Fruits give feeling of freshness and energy. It is used as carminative and astringent. It finds good utility in thyroid related disorder. The other uses reported in cardiac stimulant, swollen joints, pregnancy trouble, typhoid and comma. The dried powder used in the treatment of irritable bowel syndrome (Sharma, et al., 2007).

\section{Bael fruit}

The different parts of Bael are used for various therapeutic purposes, such as for treatment of asthma, anaemia, fractures, healing of wounds, swollen joints, high blood pressure, jaundice, diarrhoea healthy mind and brain typhoid troubles during pregnancy (Sharma et al., 2011).

The unripe dried fruit is astringent, digestive, stomachic and used to cure diarrhea and dysentery. Sweet drink prepared from the pulp of fruits produce a soothing effect on the patients who have just recovered from bacillary dysentery. The ripe fruit is a good and simple cure for dyspepsia (Parichha, 2004; Chowdhury et al., 2008).

\section{Bael fruit products}

Various process technology for production of value added preserved products from bael fruit. Fresh bael fruit can be stored for 15 days at $30^{\circ} \mathrm{C}$ when harvested at full maturity, for 1 week at $30^{\circ} \mathrm{C}$ when harvested ripe, for 3 months at $9^{\circ} \mathrm{C}$. Fruit pulp can be stored for 6 months, when stored in heat-sealed containers. Fruit powder can be stored for a year when packed in 400 gauge polypropylene pouches and stored under dark, cool place, while fruit jam, squash and preserve can be stored for several months (ITDG, 2000). The bael fruit pulp contains many functional and bioactive compounds such as carotenoids, phenolics, alkaloids, coumarins, flavonoids, and terpenoids and has innumerable traditional medicinal uses (Karunanayake et al., 1984; Singh, 1986; Nagaraju and Rao, 1990). Thus value added products can be produced by using above process technology to reduce post harvest losses, increase shelf life, value addition and increase the income.

\section{Bael products and uses}

A large number of bael processed products (Preserve, candy, panjiri, toffee, jam etc.) are prepared and some scientist and researcher are already worked on their processed products (Rakesh et al., 2005).

\section{Preserve and candy}

Preserve and candy are prepared from mature (tender green fruit), hole or large pieces of fruits in which sugar is impregnated till it becomes tender and transparent minimum fruit portion and minimum total soluble solids in preserves should be 55 and $70 \%$, respectively (Lal et al., 1960). Fruits in general contain more than $75 \%$ water and get spoiled quickly if not stored properly. Removal of water from fruits is known to 
help in longer period of storage. The osmotic dehydration techniques not only enables the storage of fruits for a longer period but also preserve the flavor, colour and texture of the product to a great extent and prevents its microbial spoilage (Bongirwar, 1997).

"A fruit of its pieces impregnated with sugar or glucose syrup, sub piquantly drained free of syrup and dried is known as candied fruit". The total sugar content of the impregnated fruit is kept at about $75 \%$ to prevent fermentation. In case of bael candy, the fruit slices are drained subsequently free of syrup and dried at $55-60^{\circ} \mathrm{C}$ for $8-10 \mathrm{hrs}$ in oven.

\section{Bael fruit squash}

An ideal composition of bael fruit squash was found to be 50 per cent extracted pulp, $50^{\circ}$ Brix and 1 per cent acidity. The squash was chemically preserved by addition of $300 \mathrm{ppm}$ $\mathrm{SO}_{2}$ (Roy and Singh, 1979). Fruit beverages commercially contain at least 25 per cent fruit pulp or juice and 40-50 per cent TSS, besides 1 per cent acid (Srivastav and Kumar, 1993). The squash from bael fruit pulp was prepared by adjusting the TSS and by adding the preservatives like sodium metabisulphite @ 350 ppm $\mathrm{SO}_{2}$ (Bhat and Kaul, 2006), and sodium benzoate @1g/litre (Verma and Gehlot, 2006). The squash was then filled in sterilized bottles, crowned and pasteurized at $80{ }^{\circ} \mathrm{C}$ for 30 minute fallowed by cooling and wax sealing to insure air tightness (Kenghe, 2008).

\section{Bael RTS (Ready To Serve)}

The ripe fruit were washed with tap water and broken by striking against hard object. The fruit pulp along with its seeds and fibres was scooped with the help of stainless steel spoon. Amount of water equal to the weight of pulp was added. The mixture of pulp and water was then heated up to $80^{\circ} \mathrm{C}$ for 1 minute and cooled. Pulp free from seeds and fibres was then obtained by passing through 20 mesh stainless steel sieve. The extracted bael pulp was improved by adjusting the TSS by addition of sugar and acidity by the addition of citric acid (Chand and Gehlot, 2006).

\section{Toffee}

Fruit toffees generally are more nutritious than ordinary toffees, and bael fruit pulp will provide even better toffees because of its nutritional and medicinal properties. Bael fruit toffees was successfully prepared by mixing 40 parts of cane sugar, 4.5 parts of glucose, 10 parts of skim milk powder and 6 parts of hydrogenated fat to 100 parts of extracted pulp. The final moisture content of the toffee was kept at 8.5 per cent (Roy and Singh, 1979).

\section{Slab}

It is also known as leather or paper. Ripe fruits are used in its preparation. Wash ripe fruits and collect fruit pulp by breaking fruits and removing its hard shell. At $200-300 \mathrm{ml}$ of water for each one $\mathrm{kg}$ of fruit pulp, mix well and heat it up to 800C. Collect fruit pulp free of seeds and fibers by straining heated mass through stainless steel sieve. Add sugar, citric acid and potassium meta-bisulphite (KMS) to this pulp so that treated pulp contains $35 \%$ total soluble solids, $0.5 \%$ total acidity and $0.07 \%$ KMS. Boil treated pulp and spread on aluminum trays smeared with butter. Dry at 55-600C for 15-16 hrs to a moisture content of $14.5 \%$. Cut slaves of dried pulp in aluminum trays, wrap in butter paper and pack in polyethylene bags (Flow-chart 8). Addition of up to 10 per cent sugar to the 
extracted pulp was found to be ideal before drying the pulp to a moisture content of 14.5 per cent (Roy and Singh, 1979).

\section{Future prospects}

Plant tissue culture played important role in the conservation of medicinal plants in the rapid multiplication and reintroduction to nature of endangered species in the assessment and monitoring of biodiversity, as a source of new tools for conservation and in the search for new gene product of therapeutic use. Species of medicinal and aromatic plants at risk need to be multiplied with minimum loss of time and reintroduced for establishment in their natural habits. In vitro protocol for multiplication of endangered species could be very useful for those texa whose propogation through conventional means was difficult. Researchers aim to obtain increased production of secondary metabolites, increased production, higher nutritional value and greater plant resistance to adverse weather, pathogenic agent and pests.

In conclusion the management and production of bael is mostly done by unorganized sector and not much emphasis is given for its commercial utilization. As its flavor is acceptable by almost all the sections of society as a refreshing summer drink which shows that it has a lot of potential for value addition and production of by products. The review reveals that Aegle marmelos, contains a large number of phytoconstituents hence it can be used for the treatment of various disorders in human being such as, diabetes, liver toxicity, fungal infection, microbial infection, inflammation, pyrexia etc. Being a versatile species not much work has been done on this tree species to identify its usefulness hence, this review is small step to show the importance of this versatile species.

\section{References}

Aiyer, A. (1956). The antiquity of some field and forest flora of India. Bangalore Printing and Publishing Co Ltd, Bangalore.

Arul V, Miyazaki S, Dhananjayan R. (2005). "Studies on the anti-inflammatory, antipyretic and analgesic properties of the leaves of Aegle marmelos Corr." Journal of Ethnopharmacology, 96: 159-163.

B.K. Rana, U.P. Singh, V. Taneja, (1997). "Antifungal activity and kinetics of inhibition by essential oil isolated from leaves of Aegle marmelos". Journal of Ethnopharmacology, 57: 29-34.

Badam L, Bedekar SS, Sonawane KB and Joshi SP (2002). In vitro antiviral activity of Bael (Agle marmelos) upon human coxsackie viruses B1-B6. Journal of communicable, 34(2):8899.

Barthakur, NN, Arnolds NP (1989). Certain organic and inorganic constituents in bael (Aeglemarmelos Correa) fruits. Trop Agric., 3:10-14.

Bhat A, Kaul RK. (2006). Utilization of Bael for Processing. Journal of Research, SKUAST-J, 5(2):203-208.

Bongirwar DR. (1997). Application of osmotic dehydration for preservation of fruits. Indian Food Packer, 51 (1):18-21.

Chand T, Gehlot R. (2006). Utilization of bael (Aegle marmelos Correa.) for preparation and preservation of pulp. Res Crops, 7(3):887-890.

Chowdhury MGF, Islam MN, Islam MS, Islam AT and Husain MS (2008). Study on preparation and shelflife of mixed juice based on wood apple and papaya. J. Soil Nat, 2(3), 50-60.

Gopalan C, RamaSastri BV and Balasubramanian SC (1978). Nutritive 
value of Indian foods. National Institute of Nutrition, ICMR.

Gupta A.K., and Tondon N. (2004), "Review on Indian medicinal plants", Indian council of medicinal research, New Delhi, 312.

Hema C.G and Lalithakumari K (1999); "Screening of Pharmacological actions of Aegle marmelos", Indian J. Pharmac.; 20, Page No.80-85.

Hiremarh IG, Ahn YJ, Kim S. (1996). Insecticidal activity of Indian plants extracts against Nilaparvata lugens (Homoptera Delphacidae). Applied Entomology Zoological, 32(1): 159166.

ITDC (2000). Processing of wild bael fruit for rural employment and income generation. ITDC Food Chain, 27: 1517.

Jaswant, Akilandeswari, V. Loganathan, S. Manimaran and Ruckmani, (2001). "Wound healing activity of Aegle marmelos". Indian J. Pharm. Sci, 63(1), 41-44.

John L,Stevenson V (1979). The complete book of fruit. Angus and Robertson Publishers Sydney.

Kartikar KR,Basu BD (1935). Indian Medicinal Plants,; 2ndedn. 1:499-502.

Karunanayake EH, Welihinda J, Sirimanne SR and Sinnadorai G (1984). Oral hypoglycaemic activity of some medicinal plants of Srilanka. Journal of Ethnopharmacology, 11(2): 223231.

Kaushik RA, Yamdagni R,Sharma JR, Kenghe RN. (2008). Changes in quality parameters during processing and storage of Bael fruit processing for value addition and employment generation. Food Pack Com, 2(8):1012.

Lal G, Siddappa GS,Tondon GL (1960). Preservation of fruits and vegetables. Indian Council of Agricultural
Research, New Delhi,.

Lampronti I, Martello D, Bianchi N, Borgatti

M, Lambertini E, Piva R, (2003). "In vitro antiproliferative effects on human tumor cell lines of extracts from the Bangladeshi medicinal plant Aegle marmelos Correa." Phytomedicine, 10: 300-308.

Mukharjee B, Ahmad K. (1957). Riboflavin. Pakistan J BiolAgr Sci, 4:47-51.

Nagaraju N and Rao KN (1990). A survey of plant crude drugs of Rayalaseema, Andhra Pradesh Indian. Journal of Ethnopharmacology, 29(2): 137-158.

Parichha Saswati (2004). Bael (Aegle Marmelos): Nature's Most Natural Medicinal Fruit". Orissa Review.

Patel P, Mohammed S, Asdaq B (2010). "Immunomodulatory activity of methanolic fruit extract of Aegle marmelos in experimental animals" Saudi Pharmaceutical Journal.; 18(3):161-165.

Pattanayak P,Mohapatra P. (2008). Phytopharmacology of Aegle marmelos (L.). Pharmacognosy Reviews, 2(4):50-56.

Rakesh, Dhawan SS, Arya SS. (2005). Product Development: Processed Products of Bael. Processed Food Industry, 8(10): 25-27.

Roy SK, Singh RN. (1979).Bael fruit (Aegle marmelos) a potential fruit for processing. Econ Bot, 33(2):203-212.

Roy SK,Singh RN (1979). Bael fruit (Aegle marmelos) a potential fruit for processing. Econ Bot.,; 33(2):203-212.

Sahare KN, Anandhraman V, Meshram VG, Meshram SU, Reddy MV, Tumane PM, ( 2008) "Anti-microfilarial activity of methanolic extract of Vitex negundo and Aegle marmelos and their phytochemical analysis." Indian Journal of Experimental Biology.; 46(9022):128-131.

Sampath kumar K.P ,.Umadevi M, Bhowmik 
D, Singh DM, Dutta A.S. (2012). Recent Trends in Medicinal Uses and Health Benefits of Indian Traditional Herbs Aegle Marmelos. The Pharma Innovation 1(4): 70-77.

Shankarananth V, Balakrishnan N, Suresh D, Sureshpandian G, Edwin E, Sheeja E. (2007). " Analgesic activity of methanol extract of Aegle marmelos leaves." Biological Trace Element Research, 78: 258 - 259.

Sharma GN, Dubey SK, Sharma P and Sati N (2011). Medicinal values Bael (Agle marmelos). International Journal of Current Pharmaceutical Review And Research, 1(3): 12-22.

Sharma PC, Bhatia V, Bansal N and Sharma A (2007). A review on Bael Tree. Natural Product Radiance 6(2): 171178.

Singh D R (2007). Underutilized Fruits Crops of Andaman and Nicobar Islands. Underutilized and Underexploited Horticultural Crops. K. V. Peter (Ed.). New India Publishing Agency New Delhi (India).; 2:11-54.

Singh YN (1986). Traditional medicine in Fiji: some herbal folk cures used by Fiji Indians. Journal of Ethnopharmacology, 15(1):57-88.

Srivastav RP, Kumar S (1993). Fruit and vegetable preservation (Principle and practices). International Book Pub. Com. Charbagh, Lucknow, India.

Yadav NP, Chanotia CS. (2009). Phytochemical and pharmacological profile of leaves of Aegle marmelos. The pharma Review, 9: 144-149.

Bose T.K. (1985). In: Fruits of India, Tropical and Subtropical India: Naya prakashan, Calcutta. p.498-504.

Sharma P.C., Bhatia V., Bansal N., Sharma . (2007). A Review on Bael tree. Ind $J$ Nat Prod Resour, 6(2): 171-178.

Orwa C, A Mutua, Kindt R , Jamnadass R, S Anthony. 2009 Agroforestree
Database:a tree reference and selection guide version 4.0

V.B. Lambole, K. Murti, U. Kumar, P.B. Sandipkumar, V. Gajera (2010), International Journal of Pharmaceutical Sciences Review and Research, , 5, 67-72.

S. Dhankhar, S. Ruhil, M. Balhara, S. Dhankhar, A.K. Chhillar (2011), Journal of Medicinal Plants Research, , 5, 1497-1507.

Ghosh, S.N., Manna, S. and Mathew, B. 2004. Effect of season on success of grafting in custard apple under semiarid condition of West Bengal. The Hort. J, 17:89-91.

Kumar, D., Singh, S.P. and Rajput, C.B.S. 1995. Influence of environmental factors and methods of budding in bael. Ind. J. Hort., 52:170-173

Madalageri, M.B., Patil, V.S. and Nalawadi, U.G. 1991. Propagation of jamun (Syzygium cumini) by softwood wedge grafting. Myforest, 27:176-178

Maity P, Hansda D, Bandyopadhyay and Mishra DK 2009. Biological Activity of crude extracts and chemical constituents of bael, Aegle marmelos (L.) Corr.\#. Ind $J$ Experimental Biology 47: 849-861.

Pampanna, Y. and Sulikeri, G.S. 2000. Effect of season on the success and growth of softwood grafts in sapota on invigorated rayan rootstock. Karnataka J. Agril. Sci., 13:779-782

Tripathi, A., and Kumar, R. 2004. Studies on the effect of method and time of budding in bael. Haryana J. Hortl. Sci., 33:195-98.

Parmar C and Kaushal MK, Aegle marmelos (1982). In: Wild Fruits, Kalyani Publishers, New Delhi, India., 1-5.

Raghu AV, Geetha SP, Martin Gerald, Balachandran Indira, Ravindran PN, Mohanan KV. Res J Bot, 2007; 2: 186-194. 
Gupta Sandhya, Chauhan Devendra, Bala Manju 2008. Indian Journal of Horticulture,; 65(1).

Ajithkumar D and Seeni S. Plant Cell Reports, 1998; 17:422-426. 18.

Prematilake DP, Nilmini HAS and Kudagamage C. Sri Lanka 2006.Cey J Sci (Bio Sci),; 35 (1): 87-90. 19.

Hiremarh I. G., Ahn Y. J. and Kim Soon-II (1996), Insecticidal Activity of Indian Plant Extracts Against Nilaparvat Alugens (Homoptera Delphacidae), App. Entomol. Zool., 32 (1): 159-166

Thampman P.K. (Ed.) (1993), Trees and Tree Farming, Peekay Tree Crops Development Foundation, Kerala, India

Teaotia S.S., Maurya V.N. and Agnihotri B.N. (1963). Some Promising Varieties of Bael (Aegle marmelos) of Eastern Districts of Uttar Pradesh, Indian Journal Horticulture, 20, 210214.

Jauhari O.S. and Singh R.D., Bael-The Valuable Fruit, Indian Horticulture, 16 (1): 9-10 (1971)

Hayes W.B., Fruits growing in India, Kitabistan, Allahabad, India (1957)

Lambole V.B, Murti K., Kumar U., Sandipkumar P.B. and Gajera V: International Journal of Pharmaceutical Sciences Review and Research, 2010; 5: 67-72.

Daniel M: Medicinal Plants-Chemistry and properties of Medicinal Plants, IBH publication; p 147. 2006

Venkatesan D, Karrunakarn CM, Selva SK and Palani PTS 2009. Identification of Phytochemical Constituents of Aegle marmelos Responsible for Antimicrobial Activity against Selected Pathogenic Organisms. Ethnobotanical Leaflets 13: 1362-72.

Mishra M, Chandra R, Tiwari RK, Pati R and Pathak RK (2005). Micropropagation of certain under utilized fruit crops: A
Review. Small fruits Review, 4(4): 718.

Ajeethkumar and Seeni S (1998). Rapid clonal multiplication through in vitro axillary shoot proliferation of Aegle marmelos (L) Corr., a medicinal tree. Plant Cell Rep., 17(5): 422-426.

Varghese SK, Inamdar JA, Kalia K, Subramaniam RS and Natraj $M$ (1993). Micropropagation of Aegle marmelos Corr. Phytomorphol., 43(1\&2): 87-89.

Rai M, Gupta PN, Dewedi R (1991). Variability in Bael germplasm. Indian J. Plant Genet. Resour. 40:86-91.

Chundawat, B. S. 1990. Arid Fruit Culture. Oxford \& IBH Publishing Co. Pvt. Ltd. New Delhi, India.

Rana B. K,.Singh U. P and Taneja V., (1997). "Anti-fungal activity and kinectics of inhibition by essential oil isolated from leaves of Aegle marmelos", J Ethanopharmacol. 57, Page No.29-34

Pitre $S$ and Srivastava S.K.(1987), "Pharmacological, microbiological and phytochemical studies on the root of Aegle marmelos", Fitoterapia, 58, Page No.194

Patil R. H., Chaudhary B. \& Settipalli S.(2009), "Antifungal and Antiaflatoxigenic activity of Aegle marmelos Linn.", Pharmacognosy Journol, Volume 1, No. 4

Randhawa, G. S. and Chadha, K. L. 1982. Fruit drop and its control in mango and citrus. ICAR, New Delhi, p. 64.

Mahendra Pal and Misra, K. K. 2005. Effect of pollen on fruit set, fruit drop and final fruit retention in self and cross pollination in bael (Aegle marmelos). Indian Journal of Agricultural Sciences, 75, 12, 800-804.

Dhaliwal, G. S. 1977. Studies on the phenotypic variability in the F1 hybrids of almond $\mathrm{x}$ peach. Ph. D. Dissertation, PAU, Ludhiana. 
Aulakh, P. S. and Uppal, D. K. 1991. Pollination studies in almond hybrids. Progressive Horticulture, 23, 26-29.

Kitat, F. M., El-Azab, E. M. And Wehida, B. M. 1973. Effect of pollination and type of pollen on fruit set, fruit drop and yield in some lime varieties (Citrus aurantifolia Swingle). Alexandria Journal of Agricultural Research, 21, 1, 109-117.

Singh, R., Godara, N. R., Singh, R. and Dahiya, S. S. 2001. Responses of foliar application of growth regulators and nutrients in ber (Zizyphus mauritiana Lamk.) cv. Umran. Haryana Journal of Horticultural Sciences, 30, 3-4, 161-164.

Saini, P. and Sharma, N. 2010. Effect of plant bio regulators and evaporating cooling on fruit set, yield and quality of plum (Prunus salicina Lindl.) cv. Red Beaut. Progressive Horticulture, 42, 2, 220-223.

Bal, J. S. and Randhawa, J. S. 2007. Effect of NAA on fruit drop and quality of ber. Haryana Journal of Horticultural Sciences, 36, 3-4, 231-232.

Rani, R. and Brahmachari, V. S. 2001. Effect of plant growth regulators on cracking and physic-chemical composition of fruit in China litchi. Progressive Horticulture, 33, 1, 32-36.

Ansari, A. M., Sah, A., Ahmed, E. and Bhagat, B. K. 2008. Effect of plant growth regulators on physiological fruit drop in Nagpur mandarin. Green Farming, 2, 1, 53-54.

Srivastava, R. P. and Singh, L. 1969. Effect of growth substances on the quality of litchi. Hort Sciences, 1, 2, 1-6.

Munzner, R. 1960. Studies on the physiology of pollen germination and tube growth, with special reference to the action of boric acid. Biology Zbl., 79, 59-84.

Saini, R. S., Singh, S. and Deswal, R. P. S. 2004. Effect of micronutrient, plant growth regulators and soil amendment on fruit drop, cracking, yield and quality of Bael (Aegle marmelos Correa) under rainfed conditions. Indian Journal of Horticulture, 61, 2, 175-176.

Srivastava, R. P. and Singh, L. 1969. Effect of growth substances on the quality of litchi. Hort Sciences, 1, 2, 1-6.

Gupta, N. K. 1999. Clonal variation in growth, vigour and photosynthetic efficiency of Bael (Aegle marmelos Correa). Thesis, M. Sc. G.B. Pant University of Agriculture and Technology, Pantnagar. 115p.

Jaiswal, H. R. 1997. Studies on morphology and reproductive characters of some strains of Bael (Aegle marmelos Correa). Thesis, Ph.D. Dr. B. R. Ambedkar University, Agra. 273p.

Srivastava, D. 2008. Development of deficiency symptoms and fixing critical levels of nitrogen, phosphorus and potassium in Bael (Aegle marmelos Correa). Thesis Ph. D., submitted to Govind Ballabh Pant University of Agriculture and Technology, Pantnagar, India. 236p.

\section{How to cite this article:}

Neeraj, Vinita Bisht and Vishal Johar. 2017. Bael (Aegle marmelos) Extraordinary Species of India: A Review. Int.J.Curr.Microbiol.App.Sci. 6(3): 1870-1887.

doi: https://doi.org/10.20546/ijcmas.2017.603.213 